\title{
$\mathrm{PW}$ パンチを用いた高張力鋼板穴抜き部の穴広げ性と疲労特性
}

\author{
松野 崇* 栗山 幸久**
}

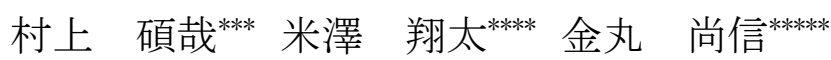

\section{Hole Expansion Ratio and Fatigue Properties in Piercing of High-Strength Steel Sheets by PW Punch}

\author{
Takashi MATSUNO*, Yukihisa KURIYAMA**, \\ Hiroya MURAKAMI ${ }^{* * *}$, Shota YONEZAWA ${ }^{* * * *}$ and Naonobu KANAMARU*****
}

(Received on June 16, 2010)

In this study, the hole expansion ratio and fatigue properties of high-strength steel sheets pierced using a "press working (PW) punch" were investigated. The PW punch, which was developed to prevent seizing between a punch and a hole surface, was reported to have the effect of smoothing a pierced edge. The PW punch increased the hole expansion ratio at a minute clearance compared with a conventional punch, and at larger clearances, the PW punch decreased it. The reason for this is considered to be the fact that the PW punch suppresses work hardening in the vicinity of the pierced surface and induces work hardening at the inner part of the pierced edge with an increase in clearance. Regarding the fatigue properties, the hole made using the PW punch had a higher fatigue limit than that made using conventional punches at large clearances. This is because a PW punch reduces roughness in the fracture zone.

Key words: shearing, piercing, hole expanding, fatigue, high-strength steel.

\section{1. 緒 言}

近年，地球温暖化防止を目的とした二酸化炭素排出規制 に伴い, 自動車部材の軽量化のニーズが高まっている。ま た, 衝突安全性確保の観点から部材に求められる強度は増 しており，鉄鋼材料に関しては部材増強と軽量化の両立を 目的に，既存の軟鋼から高張力鋼への置換が進んでいる.

軟鋼板に比べると高張力鋼板の成形性は低いため ${ }^{1)}$, そ の成形には工夫が必要である. 特に, 高張力鋼板の抜き穴

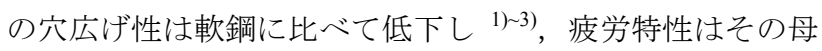
材強度並夕に向上しないことが指摘されている ${ }^{4) ~ 8)}$. 穴抜 き方法を改善してこれらの特性を向上させるべく，焼鈍打

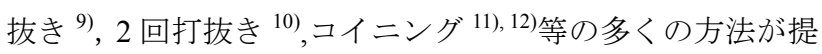
案され, その効果が実証されてきた. 穴広げ性改善を狙っ

\footnotetext{
新日本製鐵(侏) 鉄鋼研究所 $\bar{T} 293-8511$ 富津市新富 20-1 Technological Development Center, Nippon Steel Corporation, 20-1 Shintomi, Futtsu 293-8511, Japan.

詼新日本製鐵㑣) 鉄鋼研究所 同上

Technological Development Center, Nippon Steel Corporation, ibid 現在 : 横浜国立大学 安心・安全センター 二 240-8501 横浜市保土ヶ谷区常盤台 79-5

Center for Risk Management and Safety Sciences, Yokohama National University, 79-5 Tokiwadai, Hodogaya-ku, Yokohama 240-8501, Japan.

**ok 東京工業大学大学院 理工学研究科 機械物理工学専攻

干152-8552 東京都目黒区大岡山 2-12-1

Department of Mechanical Science and Engineering, Tokyo Institute of Technology, 2-12-1 Ookayama, Meguro, Tokyo 152-8552, Japan.

*owe 東京工業大学大学院 理工学研究科 機械物理工学専攻 同上 Graduate Student, ibid

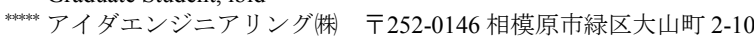
Aida Engineering, Ltd.,

2-10 Ohyama-cho, Midori, Sagamihara 252-0146, Japan.
}

た穴抜き方法ではないが，対向ダイスせん断や上下抜きに よる穴広げ性改善も報告されている ${ }^{13), 14)}$. 最も簡易な方法 としてはパンチ, ダイス間のクリアランスを調整すること で穴広げ性と疲労特性を改善することができる。森ら ${ }^{3)}$ は 超高張力鋼板の穴広げ性について調査し，クリアランスに 応じて変化する抜き穴の硬さと凹凸が主に穴広げ性を劣化 させると指摘している。 また，疲労特性については，吉武 $ら^{8)}$ はクリアランスが狭まるほど疲労特性は向上し，その 原因はクリアランスが狭まった結果として穴抜き面の破断 面粗さが低減するためであるとしている。これらの知見は いずれも，穴抜き面の平滑化により穴広げ性と疲労特性を 改善できることを示している.

微小クリアランスの穴抜きにおける焼き付き防止を目的 に開発された PW パンチ（プレスワーキングパンチ）は， その付帯効果として, 微小クリアランス以外の条件でも穴 抜き面を平滑化し, 通常のパンチを用いる場合と比べて破 断面を減少する効果がある ${ }^{15)}$. したがって，PW パンチに よる穴抜きは，パンチ交換のみで行える簡易な穴広げ性， 疲労強度改善技術として期待できる。

以上の背景のもと，本報では高張力鋼板を対象に，穴広 げ性と疲労特性に及ぼす PW パンチの効果を検証する. 微 小クリアランス下における高張力鋼板の穴広げ性と疲労特 性について明確に述べた報告はないため，合わせて，その 影響についても調査を行う. 具体的には被加工材板厚の $0.6 \%$ 微小クリアランスから $20 \%$ のクリアランスまでの 条件で PW パンチと通常のパンチによる穴抜きを行い，そ 
れらの試験片に対して穴広げ試験と疲労試験を行うことで, 穴広げ性と疲労特性に対するパンチ形状とクリアランスの 影響を明らかにする，比較として，リーマ加工穴について もその穴広げ性と疲労特性を調べ, 抜き穴, 特に微小クリ アランス穴との違いを明確にする。 さらに，抜き穴面の硬 度, 残留応力, 形状, 粗さの観点から, 得られた試験結果 に対するメカニズムの考察を行う.

\section{2. 実験条件}

\section{1 穴抜き条件と供試材}

PW パンチと通常の直角刃パンチ (以下, RA パンチと称 する）を用い，穴抜き試験を行った，PW パンチの形状を Fig.1 に，その寸法值を Table 1 に示す. PW パンチは，刃 先の面取り角 $\theta_{b}$ がチッピングを防止し, 丸み $R_{c}$ と減径部 $E$ がパンチと被加工材との接触面を減らすことで焼き付きを 防止する。このような形状はパンチ肩部付近での滑らかな 素材流動を起こすことも考慮して設計されたものである ${ }^{15)}$. 本試験においては, 形状因子を明確にするため, $\mathrm{PW}$ パン チ, RA パンチともに母材を超硬合金 V30 製とし, TiCN コ 一ティングを施した．なお，工具表面は $0.05 \mu \mathrm{mRz}$ 以下の 鏡面加工である.

穴抜きには, 最大荷重 $3000 \mathrm{kN}$ の高剛性プレス機（侏ア イダエンジニアリング製 UL3000）を使用した. ガス圧に よる板押さえを用い，その荷重はプレススライドが下死点 の際に $40 \mathrm{kN}$ となるように設定した。 また, スライドスト ロークは $120 \mathrm{~mm}$, 運動曲線は正弦波, 切り刃の噛合い量は $0.5 \mathrm{~mm}$, 毎分 50 回の打抜き速度に設定し, 潤滑油は用いな かつた。

抜き穴は試験片の中央に加工し, クリアランスは穴広げ 試験用として $0.6 \% \mathrm{t}, 2.0 \% \mathrm{t}, 5.0 \% \mathrm{t}, 12 \% \mathrm{t}, 20 \% \mathrm{t}$ の 5 種類, 疲労試験用として $0.6 \% \mathrm{t}, 12 \% \mathrm{t}$ の2種類を用いた.ここで, “\%”は鋼板の板厚に対する割合を示す.

また, 供試材には, 高張力鋼板として 590MPa 級熱延鋼 板 (析出強化材) を用いた. Table 2 にその機械特性を示す.
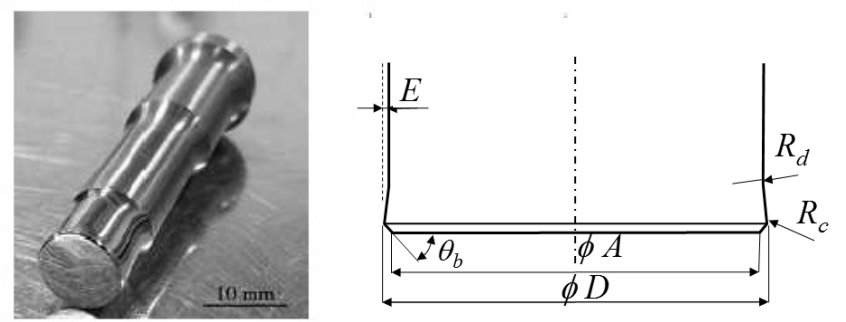

Fig. 1 Shape of PW punch

Table 1 Dimension of PW punch in Fig.1

\begin{tabular}{|c|c|c|c|c|c|}
\hline $\begin{array}{c}\phi D \\
{[\mathrm{~mm}]}\end{array}$ & $\begin{array}{c}\phi A \\
{[\mathrm{~mm}]}\end{array}$ & $\begin{array}{c}\theta_{b} \\
{[\mathrm{deg}]}\end{array}$ & $\begin{array}{c}R_{c} \\
{[\mathrm{~mm}]}\end{array}$ & $\begin{array}{c}R_{d} \\
{[\mathrm{~mm}]}\end{array}$ & $\begin{array}{c}E \\
{[\mathrm{~mm}]}\end{array}$ \\
\hline 10.0 & 9.6 & 45 & 0.1 & 13 & 0.1 \\
\hline
\end{tabular}

Table 2 Mechanical properties of the specimen

\begin{tabular}{|c|c|c|c|}
\hline $\begin{array}{c}\text { Thickness } \\
{[\mathrm{mm}]}\end{array}$ & $\begin{array}{c}\text { Yield stress } \\
{[\mathrm{MPa}]}\end{array}$ & $\begin{array}{c}\text { Tensile Stress } \\
{[\mathrm{MPa}]}\end{array}$ & $\begin{array}{c}\text { Total elongation } \\
{[\%]}\end{array}$ \\
\hline 3.2 & 509 & 612 & 27 \\
\hline
\end{tabular}

\section{2 切り口面性状の測定条件}

穴抜き, および, リーマ加工における切り口面性状の分
析のため, 切り口面の形状, 粗さ, 硬さ, および, 残留応 力の測定を行った. 以下，その測定条件を述べる.

(a) 切り口面形状と粗さ 抜き穴面の形状はせん断面率を 測定し，各水準における抜き穴面の最大粗さとして，クリ アランス $0.6 \% \mathrm{t}$ 抜き穴のせん断面粗さ, クリアランス $12 \% \mathrm{t}$ 抜き穴の破断面粗さ, および, リーマ穴加工面の粗さ (Ry, JIS-'01)を測定した。粗さ測定装置には（株）東京精密製 "SURFCOM 1900DX"を用い, せん断面, 破断面, リーマ面 の板厚方向中央部を円周方向に沿って 1 ライン測定し，そ の長さを $1.25 \mathrm{~mm}$ とした.

(b) 切り口面硬さ 抜き穴断面 - 外観形状の模式図ととも に, 硬さ測定位置を Fig.2 に示す. 抜き穴のせん断面上を, せん断開始点より $0.1 \mathrm{~mm}$ の部分を起点に板厚方向に沿っ て $0.2 \mathrm{~mm}$ ピッチで硬さを測定し(以下, 表面硬さという), さらに, かえり側の板面を起点として切り口面の輪郭形状 に沿って穴の径方向の間隔 $0.08 \mathrm{~mm}$ で 3 列（切り口面に近 い側を 1 列目とする）の硬さを $0.2 \mathrm{~mm}$ ピッチで測定した

(以下, 内部硬さという). 測定荷重は表面硬さの場合 500gf, 内部硬さの場合 $125 \mathrm{gf}$ とした.

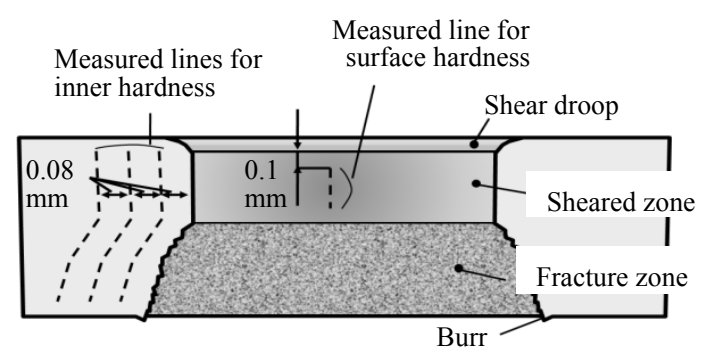

Fig.2 Position of hardness measurement on the pierced edge

(c) 切り口面残留応力 （株）理学電機製微小焦点 $\mathrm{X}$ 線応 力測定装置 PSPC-MSF 型を用い，板厚中心を基準とした $0.6 \mathrm{~mm}$ ピッチの 5 点において抜き穴の円周方向の残留応力 測定を行った. 残留応力測定用の試験片は，X線が切り口 面に当たるように，穴抜き，リーマ穴加工試験片を半分に 切断したものを使用した.

\section{3 穴広げ試験条件}

$100 \times 100 \mathrm{~mm}$ の鋼板中央に $\phi 10 \mathrm{~mm}$ の穴加工を施し， N 数を 5 として該試験片に対し対頂角が 60 度である円錐パン チによる穴広げ試験を行った，穴広げ率は，以下の式(1)に より表される。

$$
\lambda=\frac{d_{1}-d_{0}}{d_{0}} \times 100
$$

ここで $d_{0}$ は初期の打抜き穴径 $(\phi 10 \mathrm{~mm}), d_{1}$ は穴広げ時の き裂が鋼板の板厚を貫通した時点における径である。抜き 穴との比較としてリーマ穴に対しても穴広げ試験を行った. 記載以外の試験条件は日本鉄鋼連盟規格 JFS T 1001199 に 準拠した.

\section{4 疲労試験条件}

（株）東京衡機製造所製疲労試験機による平面曲げ疲労 試験を行った．試験片は $100 \times 100 \mathrm{~mm}$ の鋼板に $\phi 10 \mathrm{~mm} の$ 穴加工を施し，その穴加工部が中央となるように Fig.3 に 示す輪郭形状に切削加工した．板表面は母材のままとし， 仕上げ加工は行っていない. 
また, 試験は応力比を-1, 周波数を $25 \mathrm{~Hz}$ とし, 室温大気 中にて実施した。破断寿命は試験片が分離するまでとし， 1000 万回時間強度を疲労限とした. 応力振幅は穴部を除く 断面積でモーメントを除するネット応力にて整理した。

90

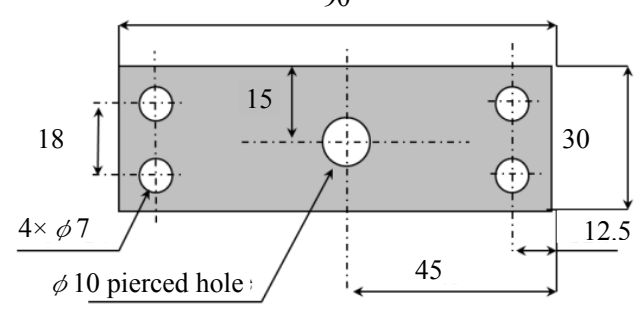

Dimension unit: $\mathrm{mm}$

Fig.3 Shape of the specimen for plane fatigue test

\section{3. 実験結果}

\section{1 切り口面性状}

(a) 切りロ面形状と粗さ 各クリアランスでの抜き穴のせ ん断面率の結果を Fig.4 に, 各クリアランスでの抜き穴面 の外観写真を Fig.5 に示す.

Fig.4 より，0.6\%t クリアランス穴で双方のパンチともに せん断面率はほぼ 100\%であり, クリアランスの増加とと もにせん断面率が減少している. その減少率は RA パンチ の方が高く, $0.6 \% \mathrm{t}$ 以外のクリアランスでは PW パンチ穴 のせん断面率が RA パンチ穴に比べて高い

また, Fig.5より, 両パンチとも抜き穴の光沢部であるせ ん断面表面に筋状の模様が確認できるが，PW パンチの方 が表面性状は良好である。クリアランス $2.0 \% \mathrm{t}$ と $5.0 \% \mathrm{t}$ に おいては，両パンチともに複数の 2 次せん断面が生じてお り，凹凸が大きいことが予測される。

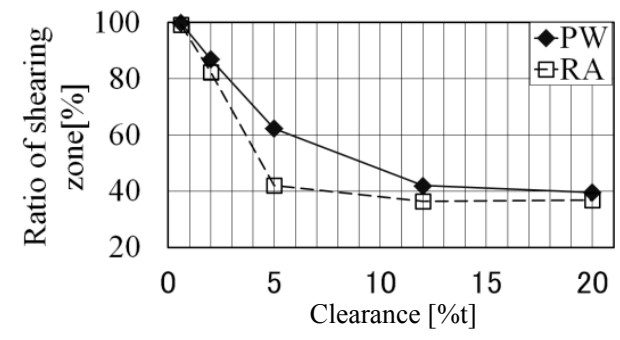

Fig.4 Ratio of the shearing zone vs. clearances

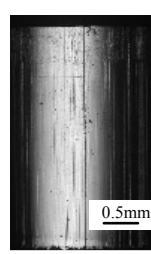

(a) PW in $0.6 \% \mathrm{t}$

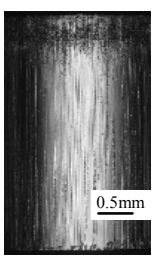

(f) RA in $0.6 \% \mathrm{t}$

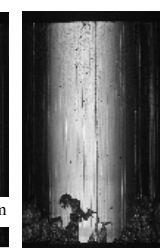

(b) PW

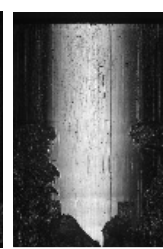

(c) $\mathrm{PW}$

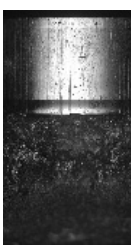

(d) PW

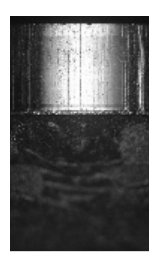

(e) PW in $2.0 \% \mathrm{t}$
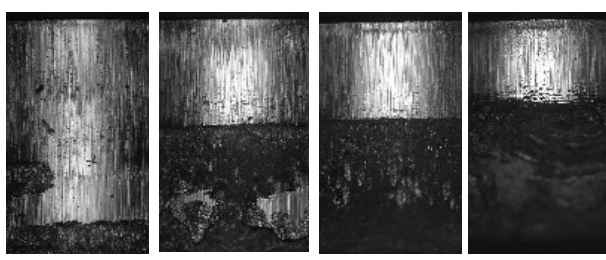

(g) RA

(h) RA

(i) RA

(j) RA in $2.0 \% \mathrm{t} \quad$ in $5.0 \% \mathrm{t} \quad$ in $12 \% \mathrm{t} \quad$ in $20 \% \mathrm{t}$

Fig. 5 Appearances of pierced surface
続いて，打抜き面粗さの測定結果を Fig.6 に示す。せん 断面の粗さはリーマ穴とほぼ同等であり破断面の粗さと比 べてその值は著しく低い．また，PW パンチ穴の破断面粗 さは RA パンチのものよりも低くなっている. RA パンチ 穴のせん断面表面の筋状模様は， RA パンチと PW パンチ 穴のせん断面粗さの差として表れているが，その差は 0.5 $\mu \mathrm{m}$ 以下であり，2つのパンチ穴のせん断面粗さはほぼ同 等であると見なせる。

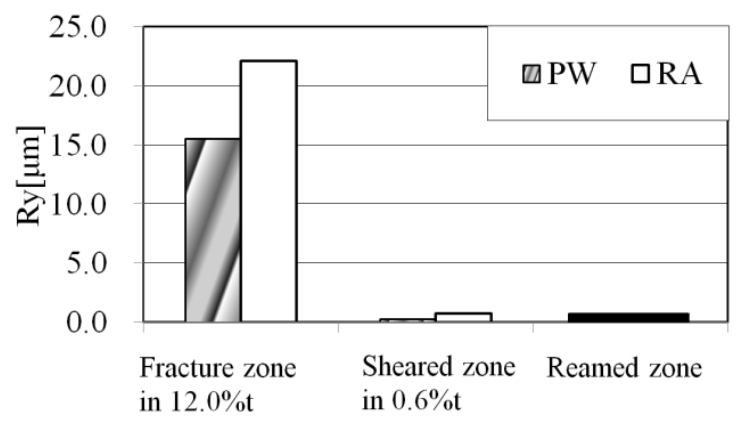

Fig.6 Roughness on the each part of hole surface

(b) 切りロ面硬さ 抜き穴の表面硬さと内部硬さの測定結 果を，それぞれ，Fig.7，Fig.8に示す。

Fig.7より何れのクリアランスにおいても PW パンチ穴の 表面硬さは RA パンチ穴よりも低い。一方，Fig.8 より測定 した 3 列（抜き穴面に近い方から 1 列目，2 列目， 3 列目） の全てで PW パンチ穴は RA パンチ穴よりも内部硬さは高 い. 特に，2 列目と 3 列目で PW パンチ穴は RA パンチ穴 よりも加工硬化が大きい。したがって， RA パンチと比較 して PW パンチは，抜き穴内部の加工硬化を誘起し，表面 の加工硬化を抑制すると見なせる.

クリアランスで比較すれば，双方のパンチによる抜き穴 で，表面硬さと 1 列目の内部硬さの差， 1 列目と 2 列目の 内部硬さの差がクリアランス量の増加とともに低下してお り，クリアランス量が小さいほど抜き穴表面に加工硬化が 集中している．特に，0.6\%t クリアランスでは， 1 列目の 内部硬さと表面硬さの差が約 $100 \mathrm{Hv}$ （最大值同士で比較） であり，抜き穴表面近傍への加工硬化の集中が著しい.

なお，リーマ穴面はほとんど加工硬化しておらず，グラ フからは除外した

(c) 切りロ面残留応力 切り口面の周方向残留応力は,

Fig.9に示す測定結果となった.

残留応力の分布は，リーマ穴と $0.6 \% \mathrm{t}$ 抜き穴では $\mathrm{PW}$ パ ンチ穴のだれ側 1 点を除いて板厚方向に一様であり，12\%t 抜き穴では破断面の中央部付近でピーク值となっている.

パンチ形状の比較では， $0.6 \% \mathrm{t}$ クリアランスで，だれ部 を除いた板厚方向のほぼ全てで PW パンチ穴の残留応力は $\mathrm{RA}$ パンチ穴よりも圧縮側となり, $12 \% \mathrm{t}$ クリアランスでは, $\mathrm{PW}$ パンチ穴は RA パンチ穴よりも引張残留応力が低くな っている．クリアランスに対する傾向としては，0.6\%t 抜 き穴は $12 \% \mathrm{t}$ 抜き穴に比べて著しく残留応力が圧縮側とな り，その值はリーマ穴とほぼ同等であった。

\section{2 穴広げ試験結果}

Fig.10に穴広げ試験結果を示す.

$\mathrm{PW}$ パンチ穴では, $0.6 \% \mathrm{t}$ から 5\%tにかけてクリアランス 
Plane material

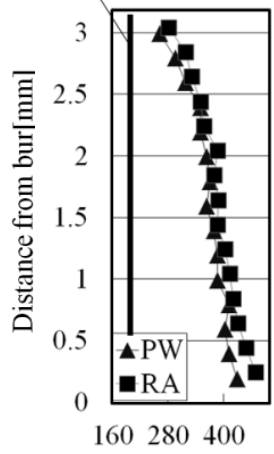

(a) $0.6 \% \mathrm{t}$

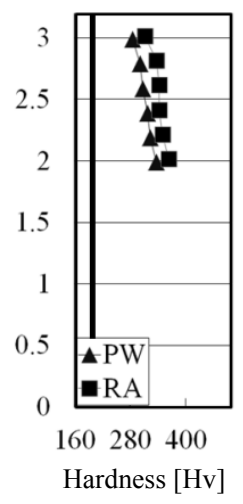

(b) $5.0 \% \mathrm{t}$

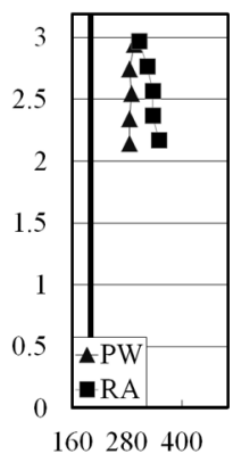

(c) $12.0 \% \mathrm{t}$

Fig.7 Surface hardness of the pierced edges

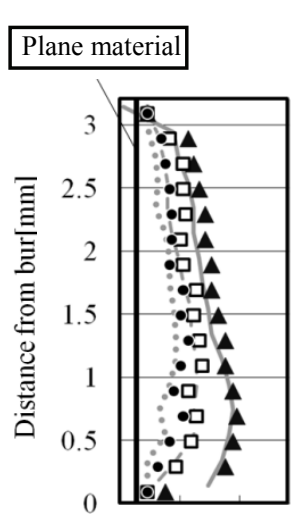

160280400

(a) $0.6 \% \mathrm{t}$

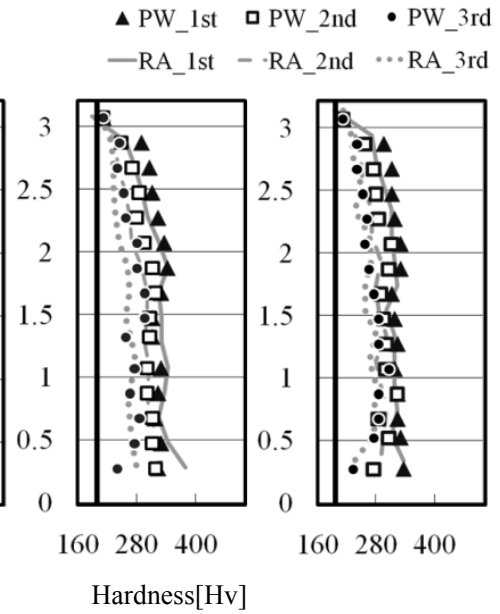

(b) $5.0 \% \mathrm{t}$

(c) $12.0 \% \mathrm{t}$
Fig.8 Inner hardness of the pierced edges

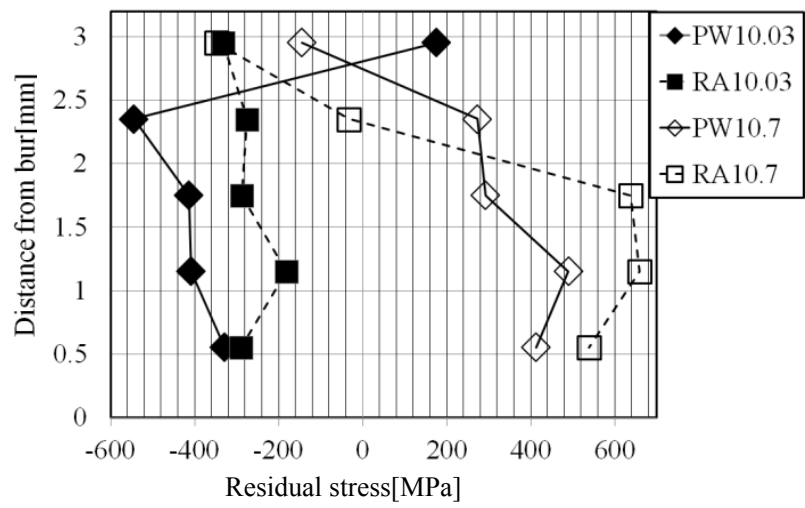

Fig.9 Residual stress of the cut edges in circumferential direction (Tensile is defined positive)

量の増大とともに穴広げ率は低下し，5\%tよりも大きなク リアランスではクリアランス量の増大とともに穴広げ率は 向上している。0.6\% に における穴広げ率が約 70\%と最も高 く, 最低值となった 5\%t での穴広げ率との差は約 30\%であ る.

$\mathrm{RA}$ パンチ穴も PW パンチ穴と同様の傾向を示し, $0.6 \% \mathrm{t}$ から $12 \% \mathrm{t}$ まではクリアランス量の増大とともに穴広げ率
は約 40\%まで低下し, $12 \%$ 以上ではクリアランス量の増大 とともに穴広げ率は向上している。穴広げ率が $65 \%$ と最も 高いクリアランスは $20 \% \mathrm{t}$ であり, 最低值(40\%)である $12 \% \mathrm{t}$ での穴広げ率との差は約 25\%であった．定量的な違いはあ るものの，RA パンチ穴の穴広げ率とクリアランスとの関 係は, 文献 ${ }^{1), 3)}$ に報告されている $590 \mathrm{MPa}$ 級高張力鋼板の傾 向に一致している。

2 つのパンチ穴の違いでは, $0.6 \% \mathrm{t}$ から $2 \% \mathrm{t}$ までのクリア ランス域で PW パンチ穴の穴広げ率が RA パンチ穴よりも 高くなり，5\%tよりも大きなクリアランス域では RA パン チ穴の穴広げ率が PW パンチ穴よりも高くなっている。リ 一マ穴を除く全ての水準の中では $0.6 \% \mathrm{t}$ における $\mathrm{PW}$ パン チ穴の穴広げ率が最大であった。

なお，グラフからは除外したが，リーマ穴の試験片は評 価装置の上限值である $140 \%$ 以上の穴広げ率であった。

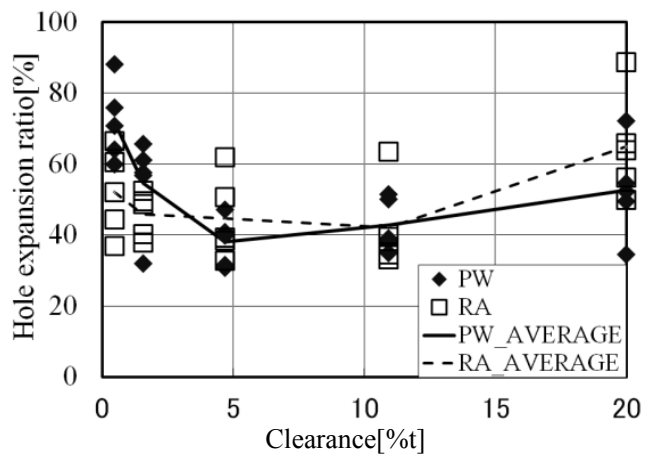

Fig. 10 Results of hole expansion tests

\section{3 疲労試験結果}

疲労試験結果として, Fig.11 に S-N 曲線を, Table 3 に疲 労限を示す.

Fig.11 より，0.6\%t クリアランスにおける PW, RA パン チ穴の全ての疲労寿命域での時間強度は $12 \% \mathrm{t}$ クリアラン スの穴のものよりも高くなっている. 0〜100 万回寿命域の リーマ穴時間強度は $12 \% \mathrm{t}$ 穴より若干高い程度であり, $0.6 \% \mathrm{t}$ の PW， RA パンチ穴よりも低い.

Table 3 より，PW パンチの効果は $12 \% \mathrm{t}$ クリアランスに おいて確認でき，その疲労限は $12 \% \mathrm{tRA}$ パンチ穴と比較し て約 $30 \mathrm{MPa}(12 \% \mathrm{tRA}$ 穴疲労限の約 $20 \%)$ 程向上している. 一方で $0.6 \% \mathrm{t}$ クリアランスでは PW パンチ穴の疲労限が若 干 RA パンチ穴よりも高くなっているが，ばらつきの範囲 内と考えられ，パンチ形状に関わらずほぼ同程度の疲労限

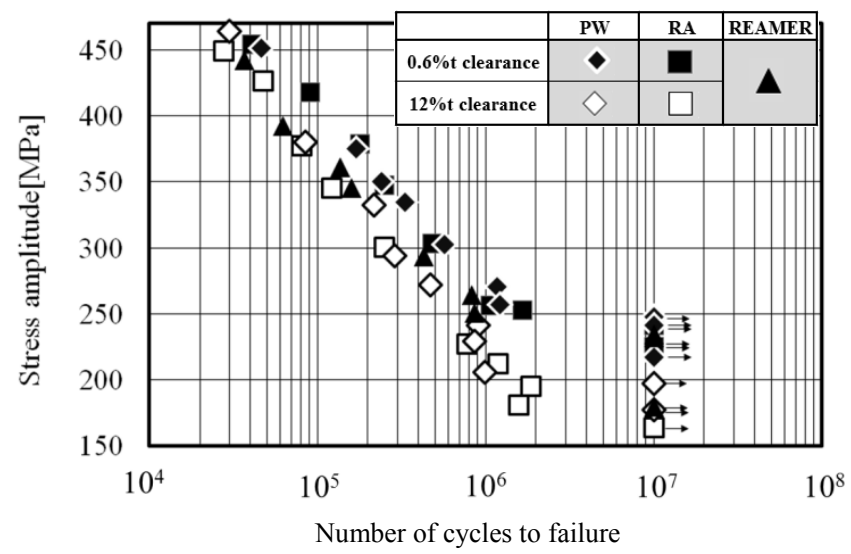

Fig.11 S-N curves of the pierced and reamed hole 
と見なすことができる. $10 \mathrm{MPa}$ の差はあるものの, リーマ 穴の疲労限も $0.6 \% \mathrm{t}$ 抜き穴とほぼ同程度であった。

Table 3 Fatigue strength of the pierced and reamed hole[MPa]

\begin{tabular}{|c|c|c|c|}
\hline & PW & RA & Reamer \\
\hline $0.6 \%$ t clearance & 247 & 242 & \multirow{2}{*}{234} \\
\hline $12 \%$ t clearance & 197 & 164 & \\
\hline
\end{tabular}

続いて, 疲労破面写真を Fig.12 に示す（図中の矢印は疲 労き裂の伝播方向を示している).

0.6\%t クリアランスでの双方のパンチ穴とリーマ穴では 疲労き裂はパンチ側とダイ側の板表面に近い抜き穴表面か らほぼ同時に発生しており，この 2 か所のき裂が伝播，会 合して試験片が破断に至っている。き裂の会合位置は Fig.12(a), (c), (e)の板厚中央部付近での段差として確認す ることができる.一方で, $12 \% \mathrm{t}$ クリアランスでは双方のパ ンチ穴ともにそのような明確な段差は確認できず, 板厚下 部側（ダイ側）の疲労破面に対して, 板厚上部側（パンチ 側）は延性破壊面に近しい破面形態となっている。この観 察結果より, $12 \% \mathrm{t}$ クリアランスで打ち抜かれた穴では疲労 き裂は破断面側のいずれかの位置で発生し，そのき裂が板 厚上部一伝播した後に, 負荷応力が素材の耐久值を超えて 延性破壊に近い状態で素材が破断したことが推察できる.

なお，上述の疲労き裂と伝播の傾向は，PW パンチ， RA パンチともに同様であった.

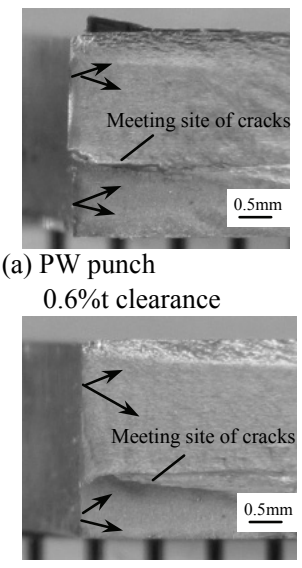

(c) RA punch $0.6 \%$ t clearance

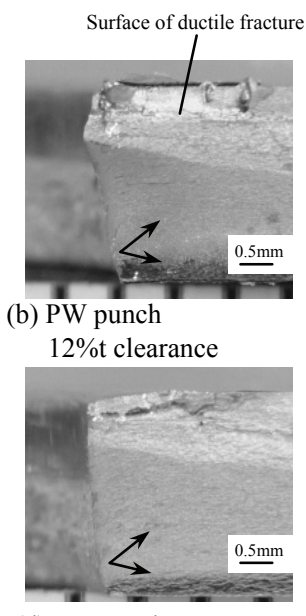

(d) RA punch $12 \%$ t clearance

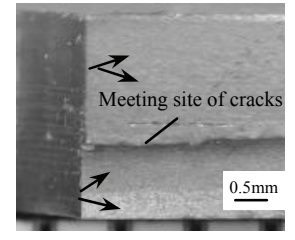

(e) Reamer

Fig.12 Fracture surface of the fatigue specimen

\section{4. 考 察}

\section{1 切り口面性状}

(a) 切り口面形状と粗さ 文献 ${ }^{6)}$ と同様に, 本報の実験にお いてもパンチ刃先の面取りのため, 穴抜き時の破断が起こ りにくくなることで PW パンチ穴のせん断面率が RA パン
チ穴よりも高くなっている．粗さがなぜ異なるかについて は，本報の実験結果からは推察することができず，そのメ カニズムの解明は今後の課題である.

(b) 切りロ面硬さ 硬さに関しては, RA パンチと比較して PW パンチ刃先の面取り部が素材変形の局所化を緩和し, より広範囲に変形を拡散させていることが，PW パンチ穴 の表面硬度が RA パンチ穴よりも低く，逆に内部硬度が高 い結果となって表れている.

(c) 切りロ面残留応力 せん断面はパンチ側面により擦ら れるため, バニシ加工されたような面となる.この，バニ シによる圧縮残留応力 ${ }^{16)}$ が打抜き面の残留応力として測 定されており, $0.6 \% \mathrm{t}$ における $\mathrm{PW}$ パンチと RA パンチ穴の 残留応力の違いは双方のパンチによるバニシ形態の違いで あると考えることができる. PW パンチの側面は，小径の 丸みを有しているためにローラーバニシ加工に近く, 平滑 な RA パンチ側面によるバニシに比較して塑性流動の量が 増えるために，穴面の残留応力がより圧縮になったと推測 される.リーマ穴については，切削時の拡径によりその切 り口面に圧縮の残留応力が付与される解析結果が示されて おり ${ }^{17)}$, 本報の実験結果においても同様の結果となってい る.

また，破断面部の引張残留応力に関しては，打抜き時に 発生するき裂の応力集中に起因していると考えられる．数 值シミュレーションによる確認が必要であるが，き裂長さ が長い程，すなわち，破断面率が大きい程応力集中は増す と考えられ，破断面率が高い $12 \% \mathrm{tRA}$ パンチ穴の破断面部 は $12 \% \mathrm{tPW}$ パンチ穴のものよりも高い引張残留応力となっ たと推測される。

\section{2 穴広げ率}

文献 ${ }^{3)}$,11),18)で指摘されているように，穴広げ率に影響す る切り口面の因子は，粗さ，凹凸，かえり，加工硬化であ り，特に加工硬化がその主因子となる．今回の実験結果で も $140 \%$ 以上の穴広げ率であるリーマ穴に対し, 加工硬化 以外の因子がほぼ同等である $0.6 \% \mathrm{t}$ クリアランスの抜き穴 の穴広げ率が 70\%程度であることから，穴広げ率に対する 加工硬化の影響が大きいことが示唆される．よって，以下 では加工硬化の観点から考察を述べる.

Fig.7, Fig.8より, 表面硬さの值はクリアランス量の増加 とともに内部硬さの值に近づく，穴広げ時の割れが抜き穴 面表層より発生すると考えれば，表面硬さの值が内部硬さ の值よりも大きいクリアランス域では穴広げ率への表面硬 さの寄与が大きく, 表面硬さの值と内部硬さの值の差が小 さいクリアランス域では内部硬度の影響が大きくなる. PW パンチによる抜き穴の穴広げ率は $0.6 \% \mathrm{t}$ から $2 \% \mathrm{t}$ のクリア ランス域で RA パンチ穴のものよりも高く，逆に $2 \%$ より 大きなクリアランス域では RA パンチ穴よりも小さくなる ことが，この考察を裏付けている.

クリアランスに対する穴広げ率の傾向は, 加工硬化の勾 配の影響と思われる。これまでに，穴広げ率に対して穴縁 の歪勾配が寄与することが調べられており，その理由は低 歪部は高歪部に対して局部くびれを防止する保護作用があ るためとされている ${ }^{19), 20)}$. 本試験の $0.6 \% \mathrm{t}$ の抜き穴では切 り口面の表面硬さは各クリアランス中最大となるが，その 穴広げ率は他のクリアランスのものと同等，または，それ 
以上となっている. 加工硬化の勾配を歪勾配と同等と捉え れば, その理由を内部硬さ $1 \sim 3$ 列目のバリ側から $0 \sim 1 \mathrm{~mm}$ に分布している加工硬化の低い部分が切り口面表層の局部 くびれを防止する保護作用として働くためと考えることが できる. Fig.7, Fig.8 よりクリアランスの増加とともに表面 硬さと内部硬さの最大值は低下し，一方で，内部硬さの 2 列目，3 列目の硬さが高くなることから硬さの低い局部く びれ保護層の領域は減少している.これらの効果が相乗し, Fig.10のように, ある特定のクリアランスで穴広げ率が最 小となるような傾向になったと思われる.

Fig.5 の破面外観より，抜き穴面の凹凸が大きい $5.0 \% \mathrm{t}$ 抜 き穴の穴広げ率が小さいとの解橎もできるが，2 次せん断 面の生じない $12 \% \mathrm{t}$ 抜き穴の穴広げ率も同様に小さいため, 凹凸のみの影響で穴広げ率が最小となるクリアランスが存 在するとは断定できない.

\section{3 疲労特性}

時間強度に関しては, 疲労き裂の伝播挙動が影響する。 そのため, 打抜き面の残留応力が時間強度を決定する主因 であると考えられる. Fig.9より, 残留応力に対するクリア ランスの影響は大きく, 最も引張残留応力の高くなった $12 \% \mathrm{t}$ 抜き穴は $0.6 \% \mathrm{t}$ 抜き穴よりも時間強度が劣っている. 一方で, 残留応力はクリアランスによる違いと比較してパ ンチ形状の影響をあまり受けておらず，そのため， $\mathrm{PW}$ パ ンチと RA パンチの間で明確な時間強度の差は現れていな い.また， $0.6 \% \mathrm{t}$ 抜き穴とリーマ穴との時間強度差の原因 は, 切り口面の残留応力がほぼ同じであるために特定する ことはできない，恐らくは， $0.6 \% \mathrm{t}$ 抜き穴で圧縮残留応力 が分布している部分（切り口面からの距離）がリーマ穴よ りも大きく, 圧縮残留応力によるき裂伝播抑制の効果が高 いために $0.6 \% \mathrm{t}$ 抜き穴の時間強度がリーマ穴よりも優れて いたと思われる。ここで, $0.6 \% \mathrm{t}$ 抜き穴の加工硬化部位は 明らかにリーマ穴よりも広く, 圧縮残留応力分布部位も同 様に広いと推測した。

疲労限に関しては, 疲労き裂の発生挙動が影響するため, 打抜き面の残留応力, 硬さ, 粗さがその因子となり, 特に 破断面粗さがその主因子であることが指摘されている ${ }^{8)}$. 本報の実験においても，1） 3.2 節に述べたように，著しく 疲労限が他の水準より劣る $12 \% \mathrm{t}$ 抜き穴には破断面が存在 し, 破断面からの疲労き裂発生と伝播が主体で素材の破断 が起こっている，2) RA パンチ穴と比較して破断面粗さの 低い(Fig.6 参照) PW パンチ穴の疲労限は RA パンチ穴より も高い值である, という点が文献 ${ }^{8)}$ の結果を裏付けている.

\section{5. 結 言}

本報では $590 \mathrm{MPa}$ 級の析出強化型高張力鋼板を対象に, クリアランスが $0.6 \% \mathrm{t}$ から $20 \% \mathrm{t}$ までの通常のパンチ（RA パンチ）と PW パンチによる抜き穴の穴広げ率と疲労特性 を調査し，以下の結果を得た。

(1) $5 \% \mathrm{t}$ 以上のクリアランス域では PW パンチ穴は抜き 穴内部の加工硬化が RAパンチによる穴抜きよりも 高くなるために, 穴広げ率が劣化した.一方で, $2 \% \mathrm{t}$ 以下の小クリアランス域において PW パンチ穴は RA パンチ穴よりも抜き穴表面の加工硬化が低減し, 穴広げ率が改善した。
(2) PW パンチ穴は $12 \% \mathrm{t}$ クリアランスにおいて RA パ ンチ穴よりも破断面粗さが低減し, そのために疲労 限は RA パンチによる抜き穴よりも向上した.

(3) $0.6 \% \mathrm{t}$ 微小クリアランスでは, $\mathrm{PW}$ パンチによる抜 き穴， RA パンチによる抜き穴ともに疲労限と時間 強度は $12 \% \mathrm{t}$ での抜き穴よりも高く，パンチ形状に よる差異はなかった。

(4) $0.6 \% \mathrm{t}$ 微小クリアランスでは, RA パンチ, PW パン チ穴ともに, リーマ加工穴よりも穴広げ率は著しく 低く, 疲労限は同程度であり, 時間強度は劣る結果 であった。

\section{参 考 文献}

1) Woestmann, S., Kohler, T. \& Schott, M. : SAE Technical Paper, SAE-2009-01-0802(2009).

2) Comstock, R.J. Jr., Scherrerand, D.K. \& Adamczyk, R.D. : J. Mat. Eng. , 15(6) (2006),675-683.

3) Mori, K., Abe, Y. \& Suzuki, Y. : J. Mater. Process. Technol., 210 (2010), 653-659.

4) Konieczny, A. \& Henderson, T. : SAE Special Publications, SP-2103(2007), 41-50.

5) Sperle, J-O. \& Trogen, H. : Scandinavian J. Metal.,18(1989), $147-154$.

6) Shirasawa, H. : ISIJ Int., 34-3 (1994), 285-289.

7) Sanchez, L., Gutierrez-Solana, F. \& Pesquera, D. : Eng. Failure Analysis, 11(2004), 751-764.

8) 吉武明英 - 塩崎毅 - 大村雅紀：自動車技術, 33-4(2002), 203-208.

9) 町田輝史・中川威雄 : 塑性と加工, 16-172(1975), 365-370.

10) 中川威雄・吉田清太: 塑性と加工, 10-104(1969), 665-671.

11) 中川威雄・Vladimir Cupka - 高野豊春 - 町田輝史 : 塑性 と加工, 16-172(1975),365-370.

12）十代田哲夫 - 三浦正明 - 中屋道治 : 神戸製鋼技報, 54-3(2004), 29-32.

13) 近藤一義・岩間龍郎・大石孝治 : 塑性と加工, 23-262 (1982), 1058-1065.

14）安部洋平・池田豊・森謙一郎: 平成 20 年度塑性加工春 季講演会講演論文集, (2008), 35-36.

15) 村上碩哉・笠原延修・望月佳彦・金丸尚信・井村隆昭 : 塑性と加工, 50-577(2009), 119-123.

16) Murthy, R.L. \& Kotiveerachari, B. : Precision Eng. 3 (1) (1981), 172-179.

17) Kang, J., Johnson, S. W. \& Clark, A. D. : J. Eng. Mat. and Tec., 124(2002), 140-145.

18) 吉田佳典・石原裕洋 - 湯川伸樹 - 石川孝司 : 平成 21 年 度塑性加工春季講演会講演論文集，(2009)，139-140。

19）山田嘉昭：塑性と加工，4-24(1963)，885-896.

20) 後藤學・林哲録・ 三沢正幸: 日本機械学会論文集 $C$ 編, 59-565 (1993), 2855-2862. 